\title{
PENGGUNAAN CAMPUR KODE DALAM UNGGAHAN INSTAGRAM
}

\author{
Ani Mulyani ${ }^{1}$, Deva Okta Riandini ${ }^{2}$, Shavira Nia Umardi ${ }^{3}$
}

Universitas Pamulang ${ }^{1,2,3}$

Aani75704@gmail.com,devaoktar@gmail.com, shaviraniaumardi@gmail.com

\begin{abstract}
ABSTRAK
Penggunaan campur kode sudah menjadi salah satu hal yang sering ditemukan disosial media, oleh karenanya penulis melakukan penelitian tersebut khususnya instagram. Pada penelitian ini, penulis menggunakan metode deskriptif kualitatif. Objek yang diteliti dalam penelitian ini menggunakan sumber data dari unggahan-unggahan instagram yang terdapat pada akun JakartaKeras, Overheardjkt, Maudyayunda, Gitasav dan juga Achasinaga yang diperoleh melalui hasil rekam data tangkap layar pada konten atau caption yang dianggap menggunakan bahasa asing. Teori yang dijadikan landasan pada penelitian ini adalah teori Muysken (2000) beliau mendefinisikan bahwa campur kode terjadi karena adanya dua bahasa dalam satu ujaran. Penulis meneliti campur kode yang ada pada unggahan-unggahan tersebut dengan cara mendeskripsikan campur kode yang ada pada unggahan penggunanya. Adapun tujuan dari penelitian ini yaitu untuk mengetahui latar belakang, faktor serta apa saja yang menyebabkan terjadinya campur kode pada unggahan instagram tersebut. berdasarkan penelitian yang sudah dilaksanakan, penulis dapat menyimpulkan bahwa unggahan-unggahan akun instagram tersebut lebih dominan pada campur kode ekternal yang dipengaruhi oleh bahasa asing yaitu bahasa inggris. Latar belakang terjadinya campur kode dikategorikan menjadi 2 yaitu tipe yang berlatar belakang pada sikap penutur (a) untuk memperhalus ungkapan, (b) untuk menunjukan kemampuan dan (c) perkembangan dan perkenalan dengan budaya baru. Selanjutnya, tipe yang berlatar belakang pada kebahasaan (a) lebih mudah diingat, (b) tidak menimbulkan kehomoniman, (c) keterbatasan kata dan (d) akibat atau hasil yang dikehendaki. Adapun faktor-faktor penyebab terjadinya campur kode pada unggahan-unggahan tersebut antara lain maraknya penggunaan bahasa gaul, penutur terbiasa menggunakan dua bahasa atau lebih, latar belakang pendidikan pengguna serta faktor lingkungan.
\end{abstract}

Kata Kunci: sosiolinguistik, campur kode, instagram PENDAHULUAN

Bahasa merupakan alat komunikasi yang digunakan oleh manusia untuk berhubungan dengan lawan komunikasinya. Bahasa digunakan untuk mengungkapkan suatu gagasan atau ide yang ingin mereka sampaikan. Oleh karena itu, bahasa merupakan hal yang penting dalam kehidupan sosial. Menurut De Saussure (dalam Chaer dan Agustina, 2010:2) menyebutkan bahwa bahasa adalah suatu lembaga kemasyarakatan lain, yang sama dengan lembaga kemasyarakatan lain, seperti perkawinan, pewarisan harta dan sebagainya. Sementara itu, dalam kajian sosiolinguistik ada yang disebut dengan kedwibahasaan. Kedwibahasaan diartikan sebagai penggunaan dua bahasa oleh seorang penutur dalam kedwibahasaan ini munculah istilah alih kode dan campur kode.

Chaer (2010:114) mendefinisikan bahwa campur kode merupakan sebuah tutran yang digunakan oleh masyarakat tertentu dengan mencampurkan dua bahasa di dalamnya. Adapun dalam penelitian ini, penulis memfokuskan penelitian pada campur kode yang terdapat pada media sosial, 
khususnya Instagram. Salah satu trend yang ada di masyarakat saat ini adalah penggunaan campur kode yang digunakan pada sosial media. Akan tetapi, masyarakat yang menggunakan campur kode tersebut kebanyakan tidak mengetahui bahwa tulisan yang mereka ubah merupakan suatu hal yang dapat dikaji dalam kajian sosiolinguistik.

Di Era globalisasi sekarang ini, penggunaan bahasa memang sudah semakin bervariatif. Ditambah dengan teknologi informasi yang semakin berkembang, salah satu bukti kemajuan teknologi dengan adanya instagram yang membuat yang membuat interaksi masyarakat lebih mudah. Instagram merupakan salah satu media sosial yang banyak penggunanya, banyak sekali orang-orang yang menggunakan dua bahasa atau bilingualisme dalam unggahannya.

Campur kode merupakan fenomena pencampuran bahasa kedua ke dalam bahasa pertama, pencampuran bahasa asing ke dalam struktur bahasa ibu. Masalah yang akan diangkat dalam penulisan ini yaitu mengenai bentuk-bentuk campur kode dalam media sosial sosial dan penyebab terjadinya campur kode. Campur kode juga dibagi menjadi dua, yaitu campur kode keluar (outer code-mixing) dan campur kode kedalam (inner code-mixing). Campur kode keluar yaitu campur kode yang berasal dari bahasa asing sedangkan campur kode kedalam yaitu campur kode yang bersumber dari bahasa asli dari segala variasinya.

Faktor terjadinya campur kode antara lain yaitu: (1) faktor pembicara atau penutur, (2) faktor pendengar atau lawan tutur, (3) perubahan situasi dengan hadirnya orang ketiga, (4) untuk mengaskan sesuatu, (5) sebagai pengisi atau penghubung kalimat, (6) pengulangan yang digunakan untuk klarifikasi, (7) mengklarifikasi isi tuturan bagi interlocutor (lawan bicara), (8) kebutuhan leksikal karena tidak ditemukan padanan kata yang tepat, (9) keefisienan suatu pembicaraan.

Tujuan dan manfaat yang ingin dicapai dalam penelitian ini adalah dapat mendeskripsikan campur kode dalam media sosial instagram, mendeskripsikan faktor-faktor yang menyebabkan terjadinya peristiwa campur kode pada pengguna instagram dan dapat memberikan kontribusi bagi perkembangan pendidikan yang berkaitan dengan komunikasi di dalam masyarakat.

\section{TEORI DAN METODOLOGI PENELITIAN}

Metode penelitian yang digunakan dalam penelitian ini menggunakan metode deskriptif kualitatif dengan objek kajian media sosial instagram, yang menggambarkan suatu gejala sosial dengan tujuan agar dapat menjelaskan suatu situasi yang hendak diteliti dengan dukungan studi kepustakaan agar memperkuat analisa penelitian dalam membuat suatu kesimpulan dan mengungkapkan fakta dan fenomena yang terjadi saat penelitian. Data-data yang diambil bersumber dari caption dan postingan instagram Acha Sinaga, Gita Savitri Devi, Maudy Ayunda, Jakarta Keras dan Overheardjkt. Pengumpulan penelitian dilakukan dengan cara dokumentasi yang berupa screenshoot dari unggahan foto. Penulis memilih data yang diambil melalui caption dan foto dari beberapa akun di atas karena akun tersebut sering menggunakan campur kode dalam menulis caption pada hampir seluruh unggahan mereka di instagram, juga untuk mengetahui latar belakang dan alasan terjadinya campur kode pada penutur. 
Muyken (2000) mendeskripsikan bahwa campur kode campur kode terjadi karena adanya dua bahasa dalam satu ujaran ketika unsur-unsur leksikal dalam dua bahasa tersebut bergabung ke dalam satu struktur bahasa yang digunakan dalam ujaran tersebut. Untuk mengetahui latar belakang terjadinya campur kode penulis menggunakan teori Suwito (1985:77) ia mengkategorikan menjadi 2 tipe yaitu tipe yang berlatar belakang pada sikap penutur (a) untuk memperhalus ungkapan, (b) untuk menunjukan kemampuannya dan (c) perkembangan dan perkenalan dengan budaya baru. Selanjurnya, tipe yang berlatar belakang pada kebahasaan (a) lebih mudah diingat, (b) tidak menimbulkan kehomoniman, (c) keterbatasan kata dan (d) akibat atau hasil yang dikehendaki.

\section{HASIL DAN PEMBAHASAN}

\section{A. Data 1}

overheardjkt

Jakarta, Indonesia

"Gue akhir-akhir ini sering flashback

masa lalu deh."

"Kalo gue akhir-akhir ini seringnya

flash sale."

@overheardjkt

"Gue akhir-akhir ini sering flashback masa lalu."

Arti dari kata flashback adalah kata yang diambil dari bahasa Inggris dengan artian kilas balik, mengingat masa lalu atau cerita masa lalu yang sempat teringat atau sengaja diingat.

"Kalo gue akhir-akhir ini seringnya flash sale"

Dalam bahasa Indonesia, arti dari kata flash sale adalah kata yang diambil dari bahasa Inggris dengan artian penjualan kilat. Dapat diartikan, flash sale adalah suatu diskon ataupun promosi yang ditawarkan oleh e-commerce dalam kurun waktu yang singkat dan juga kuantitasnya yang terbatas.

Campur kode pada postingan tersebut terdapat pada kata flashback dan flash sale. Yang termasuk pada campur kode keluar, hal ini disebabkan oleh pengikut akun instragram tersebut lebih banyak masyarakat Ibu kota yang penduduknya berasal dari berbagai daerah maupun latar belakang pendidikan yang berbeda. Juga tak luput dari peranan bahasa gaul seperti bahasa Jaksel yang dominan menggunakan dua bahasa atau lebih. Jika dilihat dari latar belakang terjadinya campur kode menurut 
Suwito, data 1 termasuk pada campur kode tipe kedua yaitu tipe yang berlatar belakang pada kebahasaan dan termasuk pada kategori yang mudah diingat.

\section{B. Data 2}

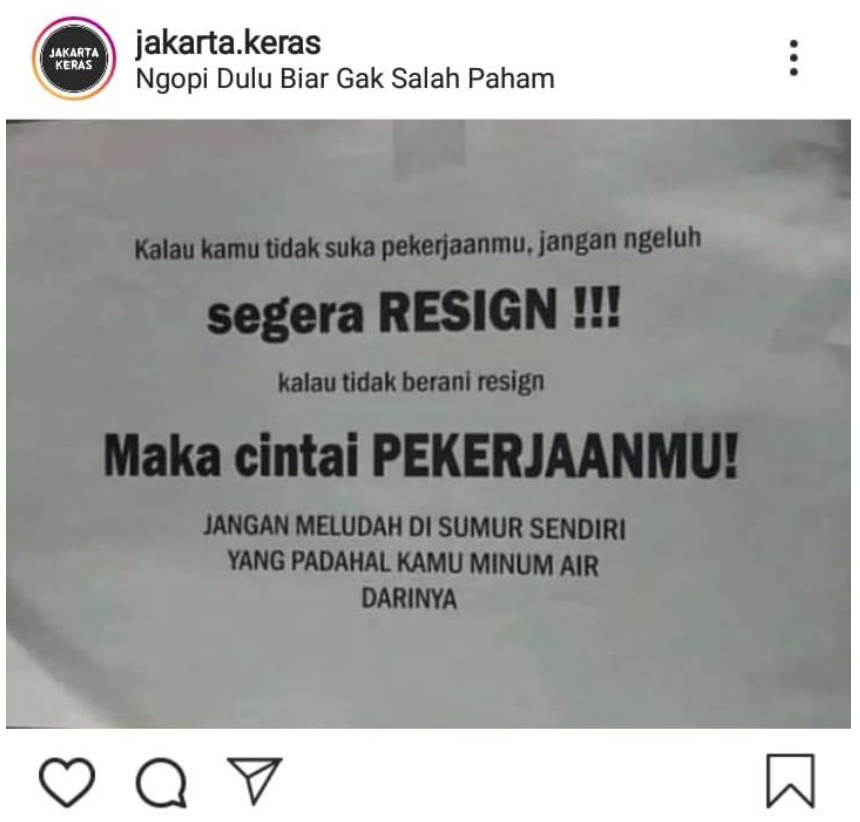

@jakarta.keras

"Kalau kamu tidak suka pekerjaanmu, jangan ngeluh segera resign!!! Kalau tidak berani resign maka cintai pekerjaanmu! Jangan meludah di sumur sendiri yang padahal kamu minum air darinya"

Adapun, istilah resign ini merupakan istilah yang berasal dari bahasa Inggris dengan artian berhenti. Resign dalam bahasa Indonesia memiliki arti mengundurkan diri, menyerah serta berhenti. Kata ini tak jarang digunakan oleh seorang pekerja yang ingin mengundurkan diri dari pekerjaannya. Namun, dari beberapa sumber kata resign tak hanya dilakukan oleh pekerja yang masih berstatus staff saja, bahkan atasan pun dapat mengundukan diri dari pekerjaannya.

Resign pada postingan akun tersebut terdapat campur kode keluar karena menyerap unsur-unsur bahasa asing dan penuturan terjadi pada situasi tidak resmi atau informal dalam unggahan akun tersebut, hal ini dipengaruhi oleh fenomena penggunaan bahasa gaul yang biasa digunakan pada kalangan milenial saat ini. Mengacu pada teori Suwito data tersebut berlatar belakang pada kebahasaan, hal ini dikarenakan kata tersebut mudah diingat dan sering digunakan dalam penuturan.

\section{Data 3}

\subsection{5 likes}

gitasav Definisi long distance relationship. Udah lama

rampung tapi baru bisa ketemu langsung

View all 220 comments 
@ gitasav

"Definisi long distance relationship. Udah lama rampung tapi baru bisa ketemu langsumg."

Pada kalimat long distance relationship merupakan kata yang diambil dari bahasa Inggris, merupakan kepanjangan dari LDR yang memiliki arti hubungan jarak jauh yang biasa dilakukan oleh pasangan kekasih.

Pada kalimat tersebut terdapat dua campur kode yaitu campur kode keluar dan kedalam. Campur kode keluar terdapat pada kata long distance relationship, hal ini dipengaruhi oleh keterbiasaan penutur dalam menggunakan bahasa asing di kehidupan sehari-hari. Juga termasuk pada campur kode yang berlatar belakang pada kebahasaan sebab kata tersebut mudah diingat dan sudah tidak asing digunakan maupun didengar pada kalangan anak muda saat ini. Pada data (3) terdapat juga campur kode pada kata "rampung" yang merupakan campur kode ke dalam karena menggunakan bahasa jawa yang dalam KBBI kata "rampung" memiliki arti selesai, beres atau usai.

\section{Data 4}

\section{maudyayunda Reunited with my room $\bullet$ tapi kayanya perlu di touch up with new furnitures + decor}

@ maudyayunda

"Reunited with my room tapi kayanya perlu di touch up with new furnitures + decor."

Pada unggahan di atas, pemilik akun memakai dua bahasa dalam unggahannya yakni bahasa Indonesia dan bahasa Inggris. Dapat diartikan pada kalimat Reunited with my room memiliki arti bersatu kembali dengan kamarku, serta pada kalimat touch up with new furnitures + decor memiliki arti disentuh dengan fitur baru dan juga dekorasi.

Campur kode keluar tersebut dapat terjadi dan dipengaruhi oleh latar belakang pendidikan penutur, yang dimana penutur terbiasa berkomunikasi dengan masyarakat yang menggunakan bahasa tersebut dalam kehidupan sehari-hari. Data tersebut termasuk pada campur kode tipe kesatu yang berlatar belakang pada sikap penutur dan termasuk pada kategori untuk menunjukan kemampuan. Hal ini dikarenakan penutur merupakan seseorang yang menjalankan pendidikan di luar negeri dengan kurun waktu yang cukup lama. 


\section{E. Data 5}

\subsection{8 likes}

achasinaga Bersyukur sekali bisa merasakan kembali

hari Sabtu yang agak lebih normal, setelah lockdown lebih dari 100 hari di Sydney Australia

@ achasinaga

"Bersyukur sekali bisa merasakan kembali hari Sabtu yang agak lebih normal, setelah lockdown lebih dari 100 hari di Sydney Australia."

Pada caption unggahan tersebut kata lockdown dapat diartikan sebagai penutupan akses di sebuah area, baik itu akses masuk maupun keluar. Dimana istilah lockdown tersebut sudah tak lagi asing didengar semenjak terjadinya pandemi virus COVID-19 yang mengharuskan beberapa negara menerapkan lockdown.

Pemilihan bahasa yang digunakan oleh penutur dapat dilatarbelakangi oleh masyarakat sekitar tempat tinggal dan juga kebiasaan penggunaan berbagai bahasa dalam komunikasi informal. Dari data tersebut, termasuk pada campur kode tipe kedua yaitu tipe yang berlatar belakang pada kebahasaan dan termasuk pada kategori keterbatasan kata. Hal ini dikarenakan kata tersebut muncul belum lama dan termasuk dalam kata baru yang digunakan pada masyarakat penutur di saat situasi pandemi.

\section{KESIMPULAN DAN SARAN}

Dapat disimpulkan dari beberapa sumber data yang kami analisis, campur kode keluar atau perpaduan antara bahasa Indonesia dengan bahasa asing lebih banyak digunakan oleh penutur dalam penulisan caption atau unggahan di media sosial instagram. Karena dipengaruhi oleh beberapa faktor diantaranya latar belakang pendidikan, penggunaan bahasa gaul dan lingkungan tempat tinggal penutur. Campur kode dapat dibagi menjadi dua yaitu campur kode keluar (outer code-mixing) dan campur kode kedalam (inner code-mixing), faktor yang mempengaruhi terjadinya Campur kode dapat disebabkan karena adanya perubahan situasi tutur dari formal ke informal.

Penelitian ini masih jauh dari kata sempurna, maka dari itu kami memohon maaf apabila terjadi kesalahan baik secara teknis maupun non teknis dalam penulisan dan penelitian ini. Kami berharap adanya penelitian lebih lanjut dan mendalam mengenai campur kode dalam berbagai bidang yang terjadi di masyarakat dengan objek yang berbeda, sehingga dapat membantu proses dan perkembangan pendidikan bahasa Indonesia. 


\section{DAFTAR PUSTAKA}

Susmita, N. Morelent, Y., \& Krisna, E. (2015). Alih kode dan campur kode dalam pembelajaran bahasa Indonesia di SMP Negeri 12 kerinci. 17(2), 87-98.

Akhii, L. Rahayu, N., \& Wulandari, C. (2018). Campur kode dan alih kode dalam percakapan di lingkup perpustakaan Universitas Bengkulu. Jurnal ilmiah korpus. 2(1), 45-55.

Nuryani. Robianti. Sahmini, M. (2018). Penggunaan campur kode dalam status media sosial facebook di desa Cinerang pada bulan Februari 2018. Jurnal Pendidikan Bahasa dan Sastra Indonesia. $1(6), 863-871$.

Amri, Y.K. (2019). Alih kode dan campur kode pada media sosial. Digital repository Universitas Negeri Medan. 2(2), 149-154.

Macaryus, dkk. 2019. Bahasa, sastra dan pembelajarannya dalam perspektif masyarakat 5.0. Yogyakarta: Program Studi Pendidikan Bahasa dan Sastra Indonesia. 